\title{
SHARIAH ISSUES IN THE APPLICATION OF TAKĀFUL: REVIEW ON ISLAMIC LAW PERSPECTIVE
}

\author{
Suharto \\ Universitas Islam Negeri (UIN) Raden Intan Lampung \\ Jl. Letkol H. Endro Suratmin Sukarame,Kota Bandar Lampung \\ Email: Lampungsuhartoradenintan@gmail.com \\ Muhammad Iqbal Fasa \\ Universitas Islam Negeri (UIN) Sunan Kalijaga Yogyakarta \\ Jl. Marsda Adisucipto Yogyakarta \\ Email: muhammadiqbalfasa@ymail.com
}

\begin{abstract}
Insurance is still debated between scholars when viewed in the light of Islamic law. Contemporary Muslim jurists are fully aware that the legal status of Insurance not been determined by Islamic law thinkers in advance (jurists). The application of Takāful today is the result of a struggle between the understanding of Islami law with the reality of what happened. Thus, the problem needs to be reviewed in the light of Islamic law in depth. This paper attempts to offer Shariah Issues in the Application of Takāful From Islamic Law Perspective, including The Concepts of Takăful(Sharia Insurance), Legal Basis of Takāful(Sharia Insurance), History of Takāful(Shariah Insurance) Development, Scholars' Views on Takāful (Sharia Insurance), The Principles of Takāful(Sharia Insurance), Establishment of Contract in Takâful (Sharia Insurance), and To Compare The Characteristics Between Takāful (Shariah Insurance) and Commercial Insurance
\end{abstract}

Abstrak. Asuransi masih diperdebatkan di antara para ilmuwan bila dilihat dari segi hukum Islam. Para Ahli hukum Islam kontemporer sadar sepenuhnya bahwa, status hukum Asuransi belum ditentukan oleh pemikir (ahli) hukum Islam terdahulu.Penerapan Takāful saat ini adalah hasil perjuangan antara pemahaman hukum islam dan realitas apa yang terjadi. Permasalahan tersebut perlu ditinjau ulang dalam tatanan hukum Islam secara mendalam. Makalah ini mencoba untuk menawarkan Aspek-aspek Syariah dalam Penerapan Takāful (Asuransi Syariah), Dasar Hukum Asuransi Takāful (Asuransi Syariah), Sejarah Perkembangan Takāful (Asuransi Syariah), Pandangan Ulama terhadap Takāful (Asuransi Syariah), Prinsip Takāful, Membandingkan Karakteristik Takāful (Asuransi Syariah) dan Asuransi Komersial.

Keyword: Islamic Law, Takāful, Sharia Insurance, Commercial Insurance

DOI: http://dx.doi.org/10.24239/jsi.v14i2.478.347-376 


\section{Introduction}

The Islamic world is faced with anxious situation. Some legal institutions and socio-economic importance has grown in the West during the last four hundred and who have made a great attack against Muslims, in the form and structure today, contrary to the values and principles presented by Islam. Insurance is still a debate scholars when viewed in the light of Islamic law. Then the problem also needs to be reviewed in the light of Islamic law. ${ }^{2}$

Contemporary Muslim jurists are fully aware that the legal status of Insurance not been determined by Islamic law thinkers in advance (jurists). Thought Takâfulas applicable today, is the result of a struggle between the understanding of Shari'a law with the reality of what happened. However, when observed through indepth study, it was found that there are serious benefits insurance that Muslim jurists (contemporary) adopts insurance management based on the principles of sharia. ${ }^{3}$

In the classical Islamic jurisprudence of the internal insurance problemthe current form of implementation is unknown, becauseit is not found in the legal status of their books. However, the study of insurance in a contemporary Islamic perspectivein fact already quite a lot done by legal experts, both expertsIslamic law in particular as well as Islamic economists in general.Given this insurance is a relatively new problem that does not yet existthe clarity of its legal status in pre Islamic times, then that debateoccurs around the law of insurance is inevitable. Some scholarsthere are forbidden for the reason of the element of usury,

${ }^{1}$ Muhammad Muslehuddin, Menggugat Asuransi Modern: Mengajukan Suatu Alternatif Baru Dalam Perspektif Hukum Islam (Jakarta: Lintera, 1999), v.

${ }^{2}$ Kuat Ismanto, Asuransi Syariah: Tinjauan Asas-Asas Hukum Islam (Yogyakarta: Pustaka Pelajar, 2009), 7.

${ }^{3}$ Burhanuddin, Aspek Hukum Lembaga Keuangan Syariah (Yogyakarta: Ilmu, 2010), 103. 
the samewith gambling, containing fraud, exploitation, and others. ${ }^{4}$

This paper focus to identify the legal basis of Takāful, Islamic insurance history, the opinion of the scholars regarding insurance, and explores in depth about aspects of sharia for insurance regarding: principles, establishment of contract, as well as the characteristics of the application of Takâful.

\section{The Concepts of Sharea Insurance (Takāful)}

The concept of insurance is not a new phenomenon in the history of human civilization. It has been around since the days of Babylon in Mesopotamia aimed at protecting private property, real estate, commercial and family affairs. Similarly, the idea and practice of Takāful is not new as it was practiced during the time of the Prophet Muhammad (PBUH) by its adoption of the concept of Aqilah. Starting the 1970s and increasingly in the 1990s, Islamic countries and other countries with a significant Muslim population have encouraged the provision of financial services, including insurance, under Islamic principles. The concept of Takâful or Islamic insurance was first introduced in Sudan in 1979, inspired by the growing needs of the Muslim consumers for an insurance protection that conforms to the Islamic law. ${ }^{5}$

Many scholars are already challenged to discuss the issue this insurance that conclusion is illegitimate business insurance, because it contains elements of gambling and usury. Even there are elements take the treasure in a way forbidden and require things that are not required by law. While the cooperative insurance ( $A t$

${ }^{4}$ Abdurrauf, "Asuransi Dalam Pandangan Ulama Fikih Kontemporer," Jurnal Al Iqtishad 2, no. 2 July (2010): 139-58.

${ }^{5}$ Sharifuddin, et al., "The Concept of Takaful (Islamic Insurance) and Its Functions in the Establishment of Syarikat Takaful Malaysia; the First Takaful Operator in Malaysia," InternationalJournal of Humanities and Social Science Invention 5, no. 12 December (2016): 43-48. 
Ta'awun) and social insurance, both are permissible, because basically is from voluntary contributions. ${ }^{6}$

According to Kabir Hasan, et.al, Takâful(Islamic Insurance) is an alternativeto the insuranceplanconventional financial, InTakāful plan, participantwillpay somecertain moneyas a donation and partly tofundrisk (participant special account), Withuse concept Tabarru '(donations) and sost preached to the insurance company. ${ }^{7}$ Mushtafa Ahmad al-Zarqa 'states the insurance contract is a system of tadlâmun and ta'âwun intended to cover the losses caused by the disaster. ${ }^{8}$

Hussen and Tismanstates Sharea Insurance(Takäful) is the basis of the principle of helping each other (At Ta'awun). Meanwhile, business practices conducted by the conventional system based on something that is not certain, to engage in activities that are prohibited under Islamic principles. ${ }^{9}$ Takāful done using Islamic ordinances, by providing security in a group together in order to avoid losses. ${ }^{10}$

Islamic insurance "Takāful" is derived from the original sources of Islamic law. The goal is as an alternative in the form of law against the practice that is prohibited form of conventional insurance. ${ }^{11} \mathrm{~A}$ Shariah insurance policy should no aspect of which

${ }^{6}$ Abdullah and Shalah, Fikih Ekonomi Keuangan Islam (Jakarta: Daarul Haq, 2004), 281.

${ }^{7}$ Wakhed Akhter, "Risk Management In Takaful," MPRA Paper, no. 40005 (2007): 2 .

${ }^{8}$ Mușțafā Aḥmad Al-Zarqā', “Aqd al-Ta”mīn Wa Mawqif al-Sharīah AlIslāmiyyah Minhu (Mecca, 1968), 405.

${ }^{9}$ Hussen and Tisman Mustaq Pasha, "Differences Between Conventional And General Takaful Insurance: Operational and Conceptua," Australian Journal Of Business And Management Research 1, no. 8 (2013): 24.

${ }^{10}$ Kabir Hasan, Introduction to Islamic Banking And Finance: Principles And Practice (England: Pearson, 2013), 292.

${ }^{11}$ Olorogun Ayinde Lukman and Abdelghani Echchabi, "Perception and Adoption of Islamic Insurance in Malaysia: An Empirical Study," World Applied Sciences Journal 20, no. 13 (2012): 407-15. 
is contrary to Islamic principles. Therefore, each element of an insurance policy sharia should really be based on sharia. ${ }^{12}$

\section{Legal Basis of Sharia Insurance (Takāful)}

Islam has laid down the foundations of this brotherhood higher as implicit or explicit in the Quran and Hadith. ${ }^{13}$ To protect the property and life due to disasters, all requiring insurance agencies that are run in accordance with Islamic principles. The cornerstone of sharia into the legal basis enactment insurance institutions in general are as follows. ${ }^{14}$

\section{Al-Qur'an}

And please doing help in the (working) virtue and piety, and do mutual assistance in sin and transgression. and ye fear Allah, Allah is severe in punishment. $^{15}$

$O$ ye who believe, fear Allah and let every self pay attention to what has been done for tomorrow (the Hereafter); and fear Allah, Surely Allah knows what you do. ${ }^{16}$

(After the waitress was met with Yusuf he shouted): "Joseph, O ye who Amat believed, Explain to Us about seven female cows are fat are eaten by seven female cows are lean and seven ears (wheat) which green and (seven) others dry, that I may return to the people, so that they know it. "Yusuf berkata:" that ye farming seven years (duration) as usual; then what you reap you shall leave dibulirnya except a little for you eat. Then after that will come seven years were very difficult, which spend what you save to deal with it (the difficult), except a little of (wheat germ) that you saved.Then after that will come in which people were given rain (enough) and in which they squeeze the grapes. ${ }^{1 n 7}$

\footnotetext{
${ }^{12}$ Mohd. Ma'sum Billah, "Source of Law Affecting Takaful (Islamic Insurance)," International Journal of Islamic Financial Services 2, no. 4 (n.d.): 19.

${ }^{13}$ Agus, et al., Solusi Berasuransi: Lebih Indah Dengan Syariah (Bandung: Salamadani, 2009), 16.

${ }^{14}$ Burhanuddin, Aspek Hukum Lembaga Keuangan Syariah.

${ }^{15}$ Q.S. al-Maidah, Verse: 5.

${ }^{16}$ Q.S. al-Hashr, Verse: 18

${ }^{17}$ Q.S. Yusuf, Verse: $46-49$.
} 


\section{Hadith}

$$
\text { المؤمن للمؤمن كالبنيان يشد بعضهم بعض }
$$

A believer to another believer is like a building which strengthens the other part (HR. Bukhari Muslim).

$$
\text { وثل المؤمنين فى توادهم وتراحمهم كمثل الجسد إذا اشتكي منه عضو تداعى له سائر الجسد بالسهر }
$$

The parable of the believers in compassion and love love is like a piece of the body. If one of its members complain of pain, the whole body aggota other people to feel pain (HR. Muslim).

\section{Opinions of Ulama}

Muslim jurists (fuqaha) are fully aware that the legal status of Takāful not been determined by Islamic law thinkers in the ancient times. ${ }^{18}$ So, in making the determination of the law, the scholars make the process of Ijtihad by reference to: Fatwa Friend, ijma', Qiyas, and Istishan.

\section{History of Sharia Insurance (Takäful) Development}

Takāful is raising funds from the participants in order to anticipate future catastrophe. Insurance fund collection practices implemented before the catastrophe. The essence of Takäful is a Risk Sharing or risk sharing together the participants, with the sense of risk borne jointly by the principle At Ta'awun (helping each other). ${ }^{19}$

In contrast to conventional insurance concept. Insurance models use tabaduli system (Transfer of Risk), where the risk was transferred to the insurance company client, with the client compensation must pay a certain amount (the premium) to the

\footnotetext{
${ }^{18}$ Zainuddin Ali, Hukum Asuransi Syariah (Jakarta: Sinar Grafika, 2008), 25.

${ }^{19}$ Panel Discussion On Subjects:Ethics and Law Transactions In Islam, Joint Prof. Dr. Syamsul Anwar, MA, on June 1, 2014.
} 
insurer. In such systems, it is possible gharar, usury and gambling, which is forbidden under Islamic law. ${ }^{20}$

Clayton stated that the idea of conventional insurance born from cultural practices Babylonians who flourished about 3000 years BC. Transactions conducted at the time referred to as the contract Bottomry. The special feature of this contract is money or items submitted in advance to the merchant for trading purposes. Money and goods given as interest bearing debt at which lend own property to determine the interest of traders out a loan or as a capital bearing debt as well as to share the profits from such trading activities. ${ }^{21}$

Insurance in Islam known as Takâful, which means the burden of risk among people, so that between one another guarantor on other risks. Takāful is an insurance which is based on Islamic principles. ${ }^{22}$

There are several terms by scholars akin to the practices of insurance. These terms are:

\section{Al-Tanāhud}

Tanăhud the like of food collected from the participants Safari (trip) mixed into one. The food then passes it on time to them, even though they get a different portion.

\section{Aqdal-Hirāsah}

Aqd al-Hirāsah is a contract security guard. In the Islamic world occurs various contracts between individuals, for example, there are people who want to be saved and then he made a contract

\footnotetext{
${ }^{20}$ Rikza Maulana, Perbandingan Sistem Asuransi Syariah Dan Konvensional (Indonesia: Takaful Indonesia, n.d.), 31.

${ }^{21}$ Sweet and Maxwell, Kontekstualisasi Takaful Dalam Asuransi Modern (Jakarta: UIN Syarif Hidayatullah, 2010), 13.

${ }^{22}$ Sofiniyah Ghufron, Sistem Operasional Asuransi Syariah (Jakarta: Renaissan, 2005), 2.
} 
with a person to maintain his safety, where he paid some money to the guards, the compensation will be guarded by security guards. ${ }^{23}$

\section{Dhimr Khatr Thariq}

This contract is a guarantee of traffic safety. Muslim traders in the past wanted to get safety protection, and then he made a contract with the people who are strong and brave in vulnerable areas. They pay a sum of money, and others maintain the safety of its journey. ${ }^{24}$

Several renowned scholars forbid conventional insurance, such as Yusuf Al-Qaradawi, Sayid Sabiq, Abdullah Al-Qalqili, Muhammad Bakhit Al-Muthi'i, Abdul Wahab Khalaf, Muhammad Yusuf Musa, Abdurrahman Isa, Mustafa Ahmad Zarqa, Muhammad Nejatullah Siddiqi. ${ }^{25}$ In the 20th century, a well-known Muslim jurist Muhammad Abduh issued two fatwas between the years 1900-1901 AD, which legalized the practice of insurance. The development of Islamic insurance practice gradually in the 20th century in various Muslim countries and non-Muslim. ${ }^{26}$

In Takāful, the insurance premiums paid participants will not necessarily be the income of insurance companies, it is collectively owned insurance participants after deduction of the management fee to the insurance company. Then, the accumulated premiums for the risks arising split among insurance participants. The role of insurance companies is limited to the role of underwriters, claim collector and payer, and fund managers. Sources of income derived from the insurance company and a management fee for the results of the investment. Each of the operating surplus or deficit of the

\footnotetext{
${ }^{23}$ Ismanto, Asuransi Syariah: Tinjauan Asas-Asas Hukum Islam.

${ }^{24}$ Ismanto.

${ }^{25}$ Agus, et al., Solusi Berasuransi: Lebih Indah Dengan Syariah, 8.

${ }^{26}$ Sweet and Maxwell, Kontekstualisasi Takaful Dalam Asuransi Modern.
} 
operation is the responsibility of the insurance participants collectively. ${ }^{27}$

Al-ta'min insurance or are anticipating to reduce the risk that can arise in people's lives in the future. Islampun has warned people to prepare themselves to face tomorrow. Future risks can be a sickness, accidents, and even death. In the business world, the risks faced may include losses due to fire, damage or loss or other risks. $^{28}$

Based on the model applied Takâful, an individual or organization to pay contributions in the form of donations with the provision that if there is a risk to the participant, the participant will receive assistance Takāfulfund to cover the losses it faces. ${ }^{29}$ All parties jointly bear the brunt of the disaster and provide disaster compensation contribution by dividing the amount of such compensation. ${ }^{30}$

Islamic insurance sector (Takäful) has expanded in many major markets and countries dominated by Muslim population around the world. ${ }^{31}$ To protect the Takaful operation of unlawful activities, usually appoint a Shariah supervisory board (DPS) to set basic rules and principles governing the operation. ${ }^{32}$

\footnotetext{
${ }^{27}$ Kementrian Negara Koperasi, Optimalisasi Manfaat Asuransi Dalam Peningkatan Akses Pembiayaan Bagi UMKM-K (Jakarta: Deputi Bidang Pembiayaan, 2009), 26.

${ }^{28}$ Fudhail Rahman, "Asuransi Dalam Perspektif Hukum Islam," Jurnal Al'Adalah 10, no. 1 (2012): 25-34.

${ }^{29}$ Muhaimin Iqbal, Asuransi Umum Syariah: Dalam Praktik Menghilangkan Gharar, Maisir, Dan Riba (Jakarta: Gema Insani Press, 2006), 23. 2006), 65.

${ }^{30}$ Husain Syahatah, Asuransi Dalam Perspektif Syariah (Jakarta: Amzah,

${ }^{31}$ Tajuddeen Olalekan Yusuf, "Prospects of Takaful's (Islamic Insurance) Contributions to the Nigerian Economy," Journal of Finance and Investment Analysis 1, no. 3 (2012): 217-30.

${ }^{32}$ Mehdi Sadeghi, "The Evolution of Islamic Insurance - Takaful: A Literature Survey," Journal of Insurance Markets and Companies: Analyzes and Actuarial Computations 1, no. 2 (2010): 100-107.
} 
Insurance, was a group that aims to establish a group to ease the financial burden of individuals and avoid financing difficulties. If such losses befell one of those who become members of the association, the losses will be borne jointly by them (Al-Ta'âwun) with the essence of the Risk sharing jointly to the participants. ${ }^{33}$ In the conventional view, Insurance uses the concept of Transfer of Risk or risk transfer. Advance money only serves as a medium of exchange. However, this time the money into one of the commodities traded in the money market or capital market even invested..$^{34}$

\section{Scholars' Views on Sharia Insurance (Takāful)}

However, the insurance problem in view of the teachings of Islam including ijtihadiyah problems, meaning that the law needs to be studied as deeply as possible because it is not explained by the Qur'an and the Hadith explicitly. The mujtahid imams such as Abu Hanifa, Imam Malik, Imam Syafe'i, Imam Ahmad Bin Hanbal, and that during her Mujtahids not give fatwa on insurance for insurance its time is not known. ${ }^{35}$

Modern insurance contract rejected by Islamic scholars or academics with a variety of reasons, and a supporter of Islamic modernism insists that this insurance shall under Islamic law. ${ }^{36}$ There are four (4) kinds of views of scholars and Muslim scholars about insurance.

\footnotetext{
${ }^{33}$ Muhammad Muslehuddin, Asuransi Dalam Islam (Jakarta: Bumi Aksara, 2004), 3.

${ }^{34}$ Ketut Sandra, Konsep Dan Penerapan Asuransi Jiwa Unit-Link Proteksi Sekaligus Investasi (Yogyakarta: Bayu Indra Grafika, 2004), 1.

${ }^{35}$ Hendi Suhendi, Fiqh Muamalah (Jakarta: Rajawali Press, 2010), 309.

${ }^{36}$ Muhammad Muslehuddin, Menggugat Asuransi Modern: Mengajukan Suatu Alternatif Baru Dalam Perspektif Hukum Islam (Jakarta: Lintera, 1999), 145.
} 
1. Found all kinds of insurance, including the form and manner of operation is haraam. ${ }^{37}$

That view is supported by several scholars, among others, Yusuf Al-Qardhowi, Sayid Sabiq, Abdullah Al-Qalqili, and Muhammad Bakhit Al-Muth'i. ${ }^{38}$ In the view of these scholars group insurance is forbidden for several reasons.

- Insurance contain elements of gambling are prohibited in Islam.

- Insurance contain elements of uncertainty.

- Insurance contains elements of "Riba" which is prohibited in Islam

- Insurance contains elements that are pressing exploitation.

- Insurance including a sale or exchange of currency are not in cash.

- Insurance business objects hung on the life and death of a person, which means that preceded the providence of God.

- The insurance company invests the money that has been paid by the insured in the form of interest guarantee. In life insurance, if the insured dies, he will be paid more than the amount of money he had paid. It is riba (profit or interest). ${ }^{39}$

2. Group of scholars who argue that insurers lawful or permissible in Islam.

Supporters view the second group of scholars, among others, Abdul Wahab Khallaf, Muh. Yusuf Musa, Abdurrahman Isa, Mustafa Ahmad Zarqa, and Muhammad Nejatullah Siddiqi. In the view of the second group, which allows insurance reasons are: ${ }^{40}$

\footnotetext{
${ }^{37}$ Warkum Sumitro, Asas-Asas Perbankan Islam \& Lembaga-Lembaga Terkait (Jakarta: Rajawali Press, 1996), 126. Terkait.

${ }^{38}$ Warkum Sumitro, Asas-Asas Perbankan Islam \& Lembaga-Lembaga

${ }^{39}$ Muhammad Muslehuddin, Asuransi Dalam Islam.

${ }^{40}$ Warkum Sumitro, Asas-Asas Perbankan Islam \& Lembaga-Lembaga Terkait.
} 
- Insurance is not gambling, nor is it a gamble, because it is based on mutuality (togetherness) and cooperation. Gambling is a game of luck, and hence undermine society. Insurance is a boon to mankind, because he was protecting them from the dangers that threaten their lives and property and provide benefits for trade and industry. ${ }^{41}$

- There is no provision nas, al-Quran and al-Hadith that forbid insurance.

- There is a willingness deal of advantages for both parties both insurer and the insured.

- The benefit of insurance more than its harm

- Including co-operative Insurance category (Syirkah Taawuniyah) are allowed in Islam.

- Insurance is a basic need for humans because of the accident and its financial consequences require compensation. ${ }^{42}$

3. Group of scholars who argue that allowed insurance is insurance for commercial purposes is prohibited in Islam.

The third view is a supported by Muhammad Abu Zahroh who arguing that social insurance is allowed because this type of social insurance do not contain elements that are forbidden in Islam.

4. Group of scholars who argue that the law of insurance, including subhat, because there is not the arguments syar'i which clearly forbids or which justifies the insurer. ${ }^{43}$

According to the National Sharia Council of Indonesian Ulema Council (DSN-MUI) in his fatwa on general guidelines for Takāful. The Indonesian Ulema Council (MUI) is an institution that issues a fatwa on halal and haram a problem for Muslims in Indonesia. The National Sharia Council (DSN) is a board established

\footnotetext{
${ }^{41}$ Muhammad Muslehuddin, Asuransi Dalam Islam.

${ }^{42}$ Hendi Suhendi, Fiqh Muamalah.

${ }^{43}$ Warkum Sumitro, Asas-Asas Perbankan Islam \& Lembaga-Lembaga Terkait.
} 
by the MUI to deal with issues related to the activities of sharia financial institutions.Takâful can be interpreted as (ta'minn, Takāful, taḍāmun) which protects mutual effort and mutual help among persons or parties through investment in assets and / or tabarru gives a pattern returns to face certain risks through contract (exchange in accordance with the sharia). ${ }^{44}$

Fatwa-fatwa National Sharia Council (DSN) related to Takāful Insurance, among others:

- Fatwa No: 21 / DSN-MUI / X / 2001 on General Guidelines for InsuranceShariah.

- Fatwa No: 51 / DSN-MUI / III / 2006 concerning Akad MudharabahMusytarakah On Sharia Insurance.

- Fatwa No. 52 / DSN-MUI / III / 2006 About Akad Wakalah Bil Ujrah onsharia Insurance and Sharia Reinsurance.

- Fatwa No: 53 / DSN-MUI / III / 2006, on Tabarru 'on Sharea Insurance.

\section{Sharea Issues in the Application of Takäful: Islamic Law Perspective}

\section{The Principles of Takāful}

Islamic Insurance (Takāful) has principles in conducting its activities. Here is the principles of Takâfulare:

\section{Tauhīd}

The principle of tauhid means that every believer, every Muslim must awaken himself to the value of monotheism, ie a full and pure belief in the unity of God and also the vertical relationship of man with god, influenced by unconditional surrender before God. ${ }^{45}$ With the aim to obtain the pleasure of Allah, where in all the process is always in the guidance of His Shari'ah. ${ }^{46}$

\footnotetext{
${ }^{44}$ See Fatwa DSN - MUI No.21 / DSN-MUI / X / 2001 About Takaful

${ }^{45}$ Syed Nawab HaidarNaqvi, Ethic and Economics, Islamic Synthesis, (London: The Islamic Foundation, 1981). 37.

${ }^{46}$ Yusuf Qardhawi, Daur Al-Qiyam Wa Al-Akhlāq Fì Al- Iqtị̣ād Al-Islām (Cairo: Muassasah al-Risalah, 2002), 23.
} 


\section{Justice ('Adl)}

Justice is the most fundamental value in Islam. Upholding justice and eradicating tyranny is the ultimate goal of His Apostles. It is often even mated with virtue and piety. ${ }^{47}$

O you who believe! Be upright for Allah, bearers of witness with justice, and let not hatred of a people incite you not to act equitably; act equitably, that is nearer to piety, and he careful of (your duty to) Allah; surely Allah is Aware of what you do.

The Qur'an and Sunnah have placed firmly the concept of justice and made it as one of the goals of the Shari'a. The fraternal value of being one of the other ultimate goals would be void and of no value, if not strengthened by justice in the allocation and resources given. ${ }^{48}$

\section{Mutual help (Ta'āwun)}

Another basic principle in conducting insurance should be based on the spirit of mutual help (ta'awun) between the member (customer). A person who is uninsured, since the beginning must have the intention and motivation to help and relieve his friend who at one time to get the unfortunate loss. ${ }^{49}$

And please help each otherin the (working) virtue and piety, and do mutual assistance in sin and transgression. and ye fear Allah, Allah is severe in punishment. ${ }^{50}$

And (remember) when Abraham prayed: "My Lord, make this country safe through the land, and give sustenance of fruit to residents who believed among them in Allah and the Last Day. ${ }^{51}$

There are some traditions that the Prophet taught Muslims to mutual caring and responsibility for others. ${ }^{52}$

\footnotetext{
${ }^{47}$ Q.S. al-Maidah (5) Verse: 8.

${ }^{48}$ Umer Chapra, The Future of Economics: An Islamic Perspective (United Kingdom: Islamic Foundation, 2000).

${ }^{49}$ Hasan Ali, Insurance in the Perspective of Islamic Law (Jakarta: Gold, 2004), 127.

${ }^{50}$ Q.S. al-Maidah (5), Verse: 2.

${ }^{51}$ Q.S. al-Baqoroh (2), Verse: 126

${ }^{52}$ Amrizal Hamsa, “Asuransi Dalam Perspektif Islam," Jurnal at-Tasyri 1, no. 2 (2009): 115-30.
} 
Among other things the hadith narrated by Bukhori Muslim as follows:

A believer to another believer is like a building which strengthens the other part (HR. Bukhari Muslim)

\section{Prohibition of Maisīr, Gharar and Ribā}

Muslim jurists consider that the operation of conventional insurance as the exchange transaction is not in line with the Sharia, by reason of elements of maysir, gharar and Riba. ${ }^{53}$ Thus, the modern insurance practices are forbidden.

They ask you about khamardan gambling. Say: "In them there is a great sin, and some benefits for humans, but sin is greater than their benefit both". and they ask you what they spend. Say: "more than necessary." Thus Allah explains His verses to you lest you think..$^{54}$

Islamic Insurance (Takāful) is also free of usury and gharar. It is asserted in the application of the principles of Islam. ${ }^{55}$

O ye who believe, do not devour usury with doubled [228]] and fear Allah and that ye may prosper. ${ }^{56}$

O you who believe! do not devour usury, making it double and redouble, and be careful of (your duty to) Allah, that you may be successful. ${ }^{57}$

The elimination and removal of usury is something that is at risk to financial risk available for sale only one party, while the other guaranteed profit. This is the so-called tyranny of one another that this is clearly forbidden in Islam. Rasulullah SAW said:

Riba is also able to cause more, but the consequences will be reduced." (HR Ahmad).

${ }^{53}$ Salako Taofiki Ajani, "The Concept and Operation of Life Insurance in the Light of Sharia," International Journal of Humanities and Social Science, 3, no. 2 (2013): 254-62.

${ }^{54}$ Q.S. al-Baqoroh (2), Verse: 219.

${ }_{55}$ Munawar Khan, "Comparative Analysis of Islamic and Insurance Prevailing Practices," International Journal of Business and Social Science 2, no. 10 (2010): 282-86.

${ }^{56}$ Q.S. al-Imron (3), Verse: 130.

${ }^{57}$ Q.S. Ali Imron (3) Verse: 130. 
Rasulullah SAW cursed the usury of usury, the giver, the author, the two witnesses, they are all the same (HR. Muslim).

According to Muslim scholars, gharar in an insurance contract can be of at least three types: ${ }^{58}$

- Uncertainty regarding the consequences of making the contract When the contract is made, neither the insurer nor the insured knowsall the circumstances that will ensue. The insured does not know whether he will receive any compensation for the money he will pay as insuranceinstallments, and the insurer does not know the amount of his futureprofits. Sometimes, the insurance company receives installments onlyonce, sometimes, several times, and in some cases it must pay out a sumthat is many times higher than the amount of installments received fromthe insured.

- Uncertainty as to whether, when peril occurs, the insurer will possess thesum required to pay out the compensation often, the insured does not know whether the insurer actually has themoney necessary to pay out the compensation, since the payment onlytakes place after the peril occurs, which may or may not occur.

- Uncertainty regarding the term of the contract. According to the principles of civil transactions in Islamic law, the termof a contract must be known by the parties thereto.

If any of the above types of gharar is present, the insurance contract will be considered void. This list coincides with the requirements of Islamic lawregarding the subject matter of a contract:

a) The subject matter of the contract must be clearly stated;

b) The quantitative characteristics of the subject matter of the contract must be specified;

${ }^{58}$ Renat I. Bekkin, "Islamic Insurance: National Features and Legal Regulation," Arab Law Quarterly 21 (2007): 3-34. 
c) The place of transfer of the subject matter of the contract must be clearly stated;

d) The subject matter of the contract must not include any items pro-hibited (barred from trade) by Shariah

In Takāful, (Takāful) elements of riba (interest), gambling (gambling) and gharar (uncertainties) are excluded from the operation..$^{59}$ In order to remove the element of uncertainty (gharar), interest (riba) and gambling (maysir) in conventional insurance operation, then that can be accomplished in accordance with Islamic principles introduced the concept Tabarru (virtue) is incorporated in it. ${ }^{60}$ Islam emphasizes the aspect of justice, consensual and togetherness at risk in every business and investment initiated. ${ }^{61}$

\section{- Trustworthly(Amanah)}

The principle of the trust in the company's organization can be realized in the values of accountability (accountability) company through the presentation of the financial statements of each period. One is that most insurance customers are obliged to convey the correct information relating to the payment of dues funds (premium) and not manipulate harm befall him.

\section{- Willingness (Ar-Ridho)}

In the insurance business, the willingness of (Ar-Ridho) can be applied to each member (customer) insurance in order to have motivation from the beginning to give up a number of funds (premiums) are payable to the insurance company, which

\footnotetext{
${ }^{59}$ Mustaq Hussain and Tisman Pasha, "Takaful Business Model: A Review, A Comparison," Journal of Business Management Dynamics 3, no. 4 (2013): 2432.

${ }^{60} \mathrm{Abdul} \mathrm{Hamid}$, et al., "Operational Issues and Shariah Harmonisation Towards the Development of Corporate Takaful Business: Conventional Debt Financing and Reinsurance Mechanism," Journal of Muamalat 3 (2010): 139-55.

${ }^{61}$ Sofiniyah Ghufron, Sistem Operasional Asuransi Syariah (Jakarta: Ranaisan, 2005), 21.
} 
functioned as a social fund (tabarru). Social Fund (tabarru) is actually used for the purpose of helping members (customers) another insurance if you have a catastrophic loss.

Islam has made perfect maintenance and guidance in the implementation of the principle of pleasure to both parties by requiring that both parties must be equally mukallaf (adult and sensible), so there is room for bargaining between the two parties. ${ }^{62}$

- Cooperation

Takāful let institutions run by promoting the principle of cooperation for mutual aid. Without the principle of cooperation, the insurance company would have difficulties to provide the maximum relief to the afflicted..$^{63}$

According Murtahdo Muntahari, Peace of the Insurance company to the customers is a job that has a value. Values listed insurance company job in an insurance contract is not a treasure to be paid later, so it is said that it is not known, the contract was canceled. But which has value in this agreement is that insurance companies give a guarantee, the customer pays a sum of money under such guarantees. ${ }^{64}$

\section{Establishment of Contract in Takāful}

The term "agreement" under Indonesian law called the "contract" in Islamic law. Said the contract was from Al-Aqd, which means binding, connecting or linking (Ar-Rabt). According to Syamsul Anwar, the contract is a meeting granted consent and a

${ }^{62}$ Ahmad Muhammad al-Assal dan Fahti Ahmad Abdul Karim, Al-Nizām Al-Iqtișādi Fì Al-Islām Mabādi'uh Wa Ahdāfuh (Cairo: Maktabah Wahbah, 1979), 196.

${ }^{63}$ Burhanuddin S, Aspek Hukum Lembaga Keuangan Syariah (Yogyakarta: Graha Ilmu, 2010), 118.

${ }^{64}$ Murtadho Muntahari, Pandangan Islam Tentang Asuransi Dan Riba (Bandung: Pustaka Hidayah, 1995), 278. 
statement of the will of two or more parties to bear some legal effect to the object. ${ }^{65}$

In Takāful, can make a new contract that Takâful Agreement, it is because these activities are activities that did not exist before. This includes the principle of freedom in contract. Takâful contract is an agreement where the parties together to raise funds to be given to the affected. The basic principle of Takâful ie At-Ta'awun (helping each other). Where is the essence of the Islamic insurance is a Risk Sharing the sharing of risk to participants. ${ }^{66}$

Agreement (contract) used in Takâful insurance is basically an investment concept. Mudhorobahgenerally use the concept of contract, but in Indonesia is using more contract in connection with the Takāful insurance company participants, such: Mudhorobah or Mudhorobah Musytarakah and Wakalah bil Ujrah. ${ }^{67}$

\section{- Akad Mudhorobah or Mudhorobah Musytarakah}

In its Operational Takāful cooperate with the Takāful participants (policyholders) on Al-Mudhorobah contract. Company Takâful Al-Mudhorib act as payee of Takāfulparticipants to be administered, invested in accordance with the principles of Shari'ah. While acting as Shahibul Maal is Takäful participants, who will benefit from protection services as well as for the results of the advantages of Takäful. ${ }^{68}$

Participants agreed on the contribution made tabarru and used to help other participants who suffered in the form of grants.

\footnotetext{
${ }^{65}$ Syamsul Anwar, Hukum Perjanjian Syariah: Studi Tentang Teori Akad Dalam Fikih Muamalat (Jakarta: Rajawali Press, 2010), 68.

${ }^{66}$ Panel Discussion On Subjects:Ethics and Law Transactions In Islam, Joint Prof. Dr. Syamsul Anwar, MA, on June 1, 2014. 2005), 210.

${ }^{67}$ Wirdyaningsih, Bank Dan Asuransi Islam Di Indonesia (Jakarta: Kencana,

${ }^{68}$ Warkum Sumitro, Asas-Asas Perbankan Islam \& Lembaga-Lembaga Terkait, 170.
} 
Takāfulinvestment profits will be returned to the participant after deducting the portion mudhorobah or operator Musharaka mudhorobah umpteen\%.

- Wakalah Bil Ujrah

The authorization of the participants to the insurance company to manage the fund participants by giving ujrah (fee). At the end of the fiscal year to approve the operator receives an incentive umpteen\% when there is an excess of revenue expenditure has been agreed, and the rest umpteen\% is reserved for distribution among the participants according to the contract of insurance.

However, no secondary contract in the implementation of Takâful. Namely, the agreement (contract) with the use of the concept of investment. Mudhorobah generally use the concept of contract, but in Indonesia is using more contract in connection with the Takâful insurance company participants, the contract mudhorobah musytarakah and wakalah ujrah bil. ${ }^{69}$ Basically, the contract Mudhorobah Musytarakah not an essence in Takāful, so it can only be used as a secondary contract. ${ }^{70}$ As known, aqad is key, without aqad then the transaction is in doubt, because it can lead to disputes at a time. Islam firmly and clearly pushed fully citizens and especially its followers to be cautious and should make aqad of each transaction that they carry out among men. ${ }^{71}$

\section{Comparison Between The Charateristicsof Takāful(Sharea Insurance) and Commercial Insurance}

The concept of insurance in Islam is the basis of the principle of helping each other. Meanwhile, business practices done by conventional systems based on a matter that is uncertain, by doing

\footnotetext{
${ }^{69}$ Wirdyaningsih, 210.

${ }^{70}$ Panel Discussion On Subjects:Ethics and Law Transactions In Islam, Joint Prof. Dr. Syamsul Anwar, MA, on June 1, 2014.

${ }^{71}$ Zainuddin Ali, Hukum Asuransi Syariah, 38.
} 
prohibited activities in the Islamic principles. The Origin of the development of sharia insurance has occurred since before the prophethood of Mohammed, with the basic concept of Aqilah. ${ }^{72}$ Sharia Insurance (Takäful) done using Islamic procedures, by providing a guarantee on a group together in order to avoid financial losses. ${ }^{73}$

In principle, the presence of insurance, both conventional or Islamic insurance is as institutions or financial services that collect public funds to provide protection to the members of the community of users of insurance against the possibility of losses due to an event that is not definitely comes as accidents, fire, died, etc. But the difference between the two is the purpose and operational system, both in terms of the structure as a system of rules that applied, as described in the following: ${ }^{74}$

Insurance agreement set the pattern of insurance transactions between participants use within each binding treaty on the rights and obligations of each party. ${ }^{75}$ Islamic insurance concept different from the concept of conventional insurance. With this concept difference, of course, will affect the operations carried out will be different from one another. ${ }^{76}$ The most fundamental difference between Takāful and conventional insurance lies in the principle ta'awun (half-bear), which became the backbone of Islamic insurance, compared with more conventional basing insurance risk transfer from the customer to the insurance company.

${ }^{72}$ Mustaq Hussen and Tisman Pasha, "Conceptual and Operational Subsequently as General Takaful and Arguments Cogently Insurance," Australian Journal of Business and Management Research 1, no. 8 (2013): 24.

${ }^{73}$ Kabir Hasan, et. al., Introduction to Islamic Banking and Finance: Principle and Practice (England: Pearson, 2013), 292.

${ }^{74}$ Sofiniyah Ghufron, et al., Sistem Operasional Asuransi Syariah, 29.

${ }^{75}$ Hendi Suhendi and Yusuf, Asuransi Takaful: Dari Teoritis Ke Praktis (Bandung: Mimbar Pustaka, 2005), 5.

${ }^{76}$ Wirdyaningsih, et al., Bank Dan Asuransi Islam Di Indonesia, 232. 
Conventional insurance principles that are contrary to Islam are the three main principles (maisir, gharar, usury). Maisir means an element of obscurity, and usury meant to contain elements of interest. ${ }^{77}$ Assets in Takāful (Takāful) must be in accordance with the assets compliance (Shariah-compliant). ${ }^{78}$

\section{The Difference Between Sharia Insurance and Commercialinsurance. ${ }^{79}$}

\begin{tabular}{|c|c|c|}
\hline The Principle & Sharia Insurance & $\begin{array}{l}\text { Commercial } \\
\text { Insurance }\end{array}$ \\
\hline Concept & $\begin{array}{l}\text { A group of people who help } \\
\text { one another, mutual } \\
\text { guarantee, and working } \\
\text { together with the way each } \\
\text { issue tabarru fund' }\end{array}$ & $\begin{array}{l}\text { The agreement } \\
\text { between the two } \\
\text { parties or more, with } \\
\text { which the Insurer } \\
\text { will bind to the } \\
\text { insured in receiving } \\
\text { the insurance } \\
\text { premiu, to give the } \\
\text { succession to the } \\
\text { insured. }\end{array}$ \\
\hline Origin & $\begin{array}{l}\text { From Al-aqilah, habit of Arab } \\
\text { tribe long before Islam came. } \\
\text { Later confirmed by the } \\
\text { Messenger to Islamic law, even } \\
\text { has spelled out in the } \\
\text { constitution of the first in the } \\
\text { world (Constitutional Madina) } \\
\text { made directly Messenger }\end{array}$ & $\begin{array}{l}\text { From the } \\
\text { community of } \\
\text { Babylonia } 4000-3000 \\
\text { BCE known with the } \\
\text { covenant of } \\
\text { Hammurabi. And the } \\
\text { year } 1668 \mathrm{M} \text { in } \\
\text { Coffee House in } \\
\text { London stand Lloyd } \\
\text { of London as the } \\
\text { precursors of } \\
\text { conventional } \\
\text { insurance }\end{array}$ \\
\hline
\end{tabular}

${ }^{77}$ Agus, et al., Solusi Berasuransi: Lebih Indah Dengan Syariah, 8.

${ }^{78}$ Nico P. Swartz1and Pieter Coetzer, "Takaful: An Islamic Insurance Instrument," Journal of Development and Agricultural Economics 2, no. 10 (2010): 333-39.

${ }^{79}$ Muhammad Syakir Sula, Asuransi Syariah (Life \& General) (Jakarta: Gema Insani Press, 2004), 326-28. 
Suharo dan Muhammad Iqbal Fasa, Shariah Issues in the Application ...

\begin{tabular}{|c|c|c|}
\hline $\begin{array}{l}\text { The source of the } \\
\text { Law }\end{array}$ & $\begin{array}{l}\text { Stems from the Divine } \\
\text { revelation. The source of the } \\
\text { law in Islamic law is the } \\
\text { Qur'an, Sunnah, Ijma', Fatwas } \\
\text { Friend, Qiyas, }\end{array}$ & $\begin{array}{l}\text { Sourced from the } \\
\text { human mind and } \\
\text { culture. Based on the } \\
\text { positive law, natural } \\
\text { law, etc. }\end{array}$ \\
\hline DPS & $\begin{array}{l}\text { There is a Council of Syariah } \\
\text { Supervisors (DPS) }\end{array}$ & $\begin{array}{l}\text { There is no Sharia } \\
\text { Supervisory Board } \\
\text { (DPS) }\end{array}$ \\
\hline Contract & $\begin{array}{l}\text { Based on } \\
\text { regulating tabarru'and } \\
\text { regulating tijarah } \\
\text { (Mudhorobah Musytarakah, } \\
\text { Wakalah Num Ujrah, Wadiah, } \\
\text { Syirkah, etc.). with the aim of } \\
\text { helping (Takäful), Tabarru'. }\end{array}$ & $\begin{array}{l}\text { Based on the } \\
\text { marriage of selling }\end{array}$ \\
\hline Guarantee/Risk & $\begin{array}{l}\text { Sharing of Risk, where a } \\
\text { process of mutual bear } \\
\text { between one participant with } \\
\text { other participants (Ta'awun). }\end{array}$ & $\begin{array}{l}\text { The Transfer of Risk, } \\
\text { where the transfer } \\
\text { of risk from the } \\
\text { insured to the } \\
\text { Insurer }\end{array}$ \\
\hline $\begin{array}{l}\text { Fund } \\
\text { management }\end{array}$ & $\begin{array}{l}\text { On these products saving } \\
\text { life segregation funds, } \\
\text { namely tabarru fund' and the } \\
\text { participantsfund, so that they } \\
\text { do not know the term funds } \\
\text { scorched. While for the } \\
\text { term insurance life and general } \\
\text { insurance all is tabarru' }\end{array}$ & $\begin{array}{l}\text { There is no } \\
\text { separation of the } \\
\text { funds, which result } \\
\text { in the funds } \\
\text { scorched (for } \\
\text { product saving the } \\
\text { live) }\end{array}$ \\
\hline Investment & $\begin{array}{l}\text { Can invest in accordance with } \\
\text { the provisions of legislation } \\
\text { throughout does not conflict } \\
\text { with the principles of Islamic } \\
\text { law. }\end{array}$ & $\begin{array}{l}\text { Free to invest in the } \\
\text { limits of the } \\
\text { provisions of } \\
\text { legislation and not } \\
\text { limited lawful and } \\
\text { haramnya objects or } \\
\text { investment system } \\
\text { that used }\end{array}$ \\
\hline $\begin{array}{l}\text { Ownership of } \\
\text { funds }\end{array}$ & $\begin{array}{l}\text { The collected funds from the } \\
\text { premium of the participants in } \\
\text { the form of fees or } \\
\text { contribution, is owned by the }\end{array}$ & $\begin{array}{l}\text { The collected funds } \\
\text { from the premium } \\
\text { participants entirely } \\
\text { become the property }\end{array}$ \\
\hline
\end{tabular}




\begin{tabular}{|c|c|c|}
\hline & $\begin{array}{l}\text { participants (shahibul mal), } \\
\text { sharia insurance only as the } \\
\text { holder of the } \\
\text { mandate (mudhorib)in } \\
\text { managing the funds. }\end{array}$ & $\begin{array}{l}\text { of the company. The } \\
\text { company is free to } \\
\text { use and invest to } \\
\text { anywhere. }\end{array}$ \\
\hline $\begin{array}{l}\text { Premium } \\
\text { elements }\end{array}$ & $\begin{array}{l}\text { Premium element consists of } \\
\text { elements of tabarru and } \\
\text { savings. Tabarrualso } \\
\text { calculated from the table } \\
\text { mortalita, but without the } \\
\text { interest calculation. }\end{array}$ & $\begin{array}{l}\text { Premium elements } \\
\text { consists of vascular } \\
\text { surgery mortalita } \\
\text { table (table), } \\
\text { interest (interest), } \\
\text { costs insurance (cost } \\
\text { of insurance) }\end{array}$ \\
\hline Loading & $\begin{array}{l}\text { Loading (commission) agent } \\
\text { does not burden on } \\
\text { participants, but on the } \\
\text { shareholders. }\end{array}$ & $\begin{array}{l}\text { Loading on the } \\
\text { conventional } \\
\text { insurance is big } \\
\text { enough especially } \\
\text { allocated to the } \\
\text { commission agent. }\end{array}$ \\
\hline $\begin{array}{l}\text { The source of } \\
\text { Claim Payment }\end{array}$ & $\begin{array}{l}\text { Obtained from a } \\
\text { funds tabarru', namely } \\
\text { participants bear. If one of the } \\
\text { participants received a } \\
\text { tragedy, then other } \\
\text { participants joined bear } \\
\text { together. }\end{array}$ & $\begin{array}{l}\text { From the account of } \\
\text { the company as a } \\
\text { consequence of the } \\
\text { insurer to the } \\
\text { insured. Business } \\
\text { pure and there is no } \\
\text { spiritual nuance. }\end{array}$ \\
\hline $\begin{array}{l}\text { Accounting } \\
\text { System }\end{array}$ & $\begin{array}{l}\text { Embraced the concept of } \\
\text { accounting cash basis, admit } \\
\text { what really was. }\end{array}$ & $\begin{array}{l}\text { Menganur concept of } \\
\text { accounting accrual basis, } \\
\text { namely accounting process } \\
\text { that acknowledges that the } \\
\text { event or situation nonkas. }\end{array}$ \\
\hline Benefits & $\begin{array}{l}\text { The profit obtained from } \\
\text { the surplus, reinsurance } \\
\text { commission and the result of } \\
\text { investment is not entirely } \\
\text { become the property of the } \\
\text { company, but a recent study } \\
\text { for the } \\
\text { results (mushorobah) with } \\
\text { participants. }\end{array}$ & $\begin{array}{l}\text { The benefits from } \\
\text { a surplus of } \\
\text { underwriting, } \\
\text { reinsurance } \\
\text { commission, and the } \\
\text { results of the whole } \\
\text { investment is } \\
\text { corporate profits. }\end{array}$ \\
\hline $\begin{array}{l}\text { Mission and } \\
\text { Vision }\end{array}$ & $\begin{array}{l}\text { The mission of embracing in } \\
\text { sharia insurance is the mission } \\
\text { of worldly matters, mission of }\end{array}$ & $\begin{array}{l}\text { Outline the main } \\
\text { mission of } \\
\text { conventional }\end{array}$ \\
\hline
\end{tabular}


Suharo dan Muhammad Iqbal Fasa, Shariah Issues in the Application ...

\begin{tabular}{ll}
\hline $\begin{array}{ll}\text { worship, (Ta'awun), economic } \\
\text { mission (iqtishod), and the }\end{array}$ & $\begin{array}{l}\text { insurance is the } \\
\text { mission of the empowerment } \\
\text { of the people. }\end{array}$ \\
\hline
\end{tabular}

As known, the philosophy of Takâful is very strong nuanced worship, especially in muamalah practice as well as social nuances with emphasis on theology and Islamic morality. Philosophical sharia insurance is intended solely to help (at-ta'awun) on the basis of brotherhood among Muslims and simultaneously building a shared responsibility, cooperate with each other and protect each other from various troubles. ${ }^{80}$

\section{Conclusion}

The concept of insurance is not a new phenomenon in the history of human civilization. It has been around since the days of Babylon in Mesopotamia aimed at protecting private property, real estate, commercial and family affairs. Similarly, the idea and practice of Takāful is not new as it was practiced during the time of the Prophet Muhammad (PBUH) by its adoption of the concept of Aqilah. Starting the 1970s and increasingly in the 1990s, The concept of Takâful or Islamic insurance was first introduced in Sudan in 1979, inspired by the growing needs of the Muslim consumers for an insurance protection that conforms to the Islamic law.

Takāful (Islamic Insurance) is an alternative to the insurance plan conventional financial, In Takāful plan, participant will pay some certain money as a donation and partly to fund risk (participant special account), Withuse concept Tabarru ' (donations) and sost preached to the insurance company.

The cornerstone of sharia into the legal basis enactment insurance institutions include in quran and hadits such: Qur'an

\footnotetext{
${ }^{80}$ Agus, et al., Solusi Berasuransi: Lebih Indah Dengan Syariah,16.
} 
Surah Al-Maidah, Verse: 5, Surah Al-Hashr, Verse: 18, Surah Yusuf, Verse: 46-49, and HR Muslim.

There are four (4) kinds of views of scholars and Muslim scholars about insurance. First, found all kinds of insurance, including the form and manner of operation is haraam. Second, group of scholars who argue that insurers lawful or permissible in Islam. Third, group of scholars who argue that allowed Takâfulbut insurance for commercial purposes is prohibited in Islam. Fourth, Group of scholars who argue that the law of insurance, including subhat, because there is not the syar'i arguments which clearly forbids or which justifies the insurer.

Islamic Insurance (Takâfun) has principles in conducting its activities, such as: Tawheed, Justice ('Adl), Mutual help (Ta'awun), Prohibition of Maysir, Gharar and Riba, Trustworthly (Amanah), Willingness (Ar-Ridho), Cooperation. Agreement (contract) used in Takäfulinsurance is basically an investment concept. Mudhorobah generally use the concept of contract, but in Indonesia is using more contract in connection with the Takāful insurance company participants, such: Mudhorobah or Mudhorobah Musytarakah and Wakalah bil Ujrah

\section{References}

Abdullah, and Shalah. Fikih Ekonomi Keuangan Islam. Jakarta: Daarul Haq, 2004.

Abdurrauf. "Asuransi Dalam Pandangan Ulama Fikih Kontemporer." Jurnal Al Iqtishad 2, no. 2 July (2010): 139-58.

Agus. Solusi Berasuransi: Lebih Indah Dengan Syariah. Bandung: Salamadani, 2009.

Ajani, Salako Taofiki. "The Concept and Operation of Life Insurance in the Light of Sharia." International Journal of Humanities and Social Science, 3, no. 2 (2013): 254-62.

Akhter, Wakhed. "Risk Management In Takaful." MPRA Paper, no. 
Suharo dan Muhammad Iqbal Fasa, Shariah Issues in the Application ...

40005 (2007): 2.

Al-Zarqā’, Mușțafā Aḥmad. “Aqd al-Ta”mīn Wa Mawqif al-Sharīah Al- Islāmiyyah Minhu. Mecca, 1968.

Ali, Hasan. Insurance in the Perspective of Islamic Law. Jakarta: Gold, 2004.

Anwar, Syamsul. Hukum Perjanjian Syariah: Studi Tentang Teori Akad Dalam Fikih Muamalat. Jakarta: Rajawali Press, 2010.

Bekkin, Renat I. "Islamic Insurance: National Features and Legal Regulation." Arab Law Quarterly 21 (2007): 3-34.

Billah, Mohd. Ma'sum. "Source of Law Affecting Takaful (Islamic Insurance)." International Journal of Islamic Financial Services 2, no. 4 (n.d.): 1-9.

Burhanuddin. Aspek Hukum Lembaga Keuangan Syariah. Yogyakarta: Ilmu, 2010.

Chapra, Umer. The Future of Economics: An Islamic Perspective. United Kingdom: Islamic Foundation, 2000.

Coetzer, Nico P. Swartz1and Pieter. "Takaful: An Islamic Insurance Instrument." Journal of Development and Agricultural Economics 2, no. 10 (2010): 333-39.

Fudhail Rahman. “Asuransi Dalam Perspektif Hukum Islam.” Jurnal Al'Adalah 10, no. 1 (2012): 25-34.

Ghufron, Sofiniyah. Sistem Operasional Asuransi Syariah. Jakarta: Ranaisan, 2005.

Hamid, Abdul. "Operational Issues and Shariah Harmonisation Towards the Development of Corporate Takaful Business: Conventional Debt Financing and Reinsurance Mechanism." Journal of Muamalat 3 (2010): 139-55.

Hamsa, Amrizal. "Asuransi Dalam Perspektif Islam." Jurnal atTasyri 1, no. 2 (2009): 115-30. 
Hasan, Kabir. Introduction to Islamic Banking and Finance: Principle and Practice. England: Pearson, 2013.

Hasan, Kabir. Introduction to Islamic Banking And Finance: Principles And Practice. England: Pearson, 2013.

Hendi Suhendi. Fiqh Muamalah. Jakarta: Rajawali Press, 2010.

Hussain, Mustaq, and Tisman Pasha. "Takaful Business Model: A Review, A Comparison." Journal of Business Management Dynamics 3, no. 4 (2013): 24-32.

Hussen, Mustaq, and Tisman Pasha. "Conceptual and Operational Subsequently as General Takaful and Arguments Cogently Insurance." Australian Journal of Business and Management Research 1, no. 8 (2013): 24.

Hussen, and Tisman Mustaq Pasha. "Differences Between Conventional And General Takaful Insurance: Operational and Conceptua." Australian Journal of Business And Management Research 1, no. 8 (2013): 24.

Ismanto, Kuat. Asuransi Syariah: Tinjauan Asas-Asas Hukum Islam. Yogyakarta: Pustaka Pelajar, 2009.

Karim, Ahmad Muhammad al-Assal dan Fahti Ahmad Abdul. AlNiz̄ām Al-Iqtiṣādi Fì Al-Islām Mabādi'uh Wa Ahdāfuh. Cairo: Maktabah Wahbah, 1979.

Kementrian Negara Koperasi. Optimalisasi Manfaat Asuransi Dalam Peningkatan Akses Pembiayaan Bagi UMKM-K. Jakarta: Deputi Bidang Pembiayaan, 2009.

Khan, Munawar. "Comparative Analysis of Islamic and Insurance Prevailing Practices." International Journal of Business and Social Science 2, no. 10 (2010): 282-86.

Lukman, Olorogun Ayinde, and Abdelghani Echchabi. "Perception and Adoption of Islamic Insurance in Malaysia: An Empirical Study." World Applied Sciences Journal 20, no. 13 (2012): 407- 
15.

Mehdi Sadeghi. "The Evolution of Islamic Insurance - Takaful: A Literature Survey." Journal of Insurance Markets and Companies: Analyzes and Actuarial Computations 1, no. 2 (2010): 100-107.

Muhaimin Iqbal. Asuransi Umum Syariah: Dalam Praktik Menghilangkan Gharar, Maisir, Dan Riba. Jakarta: Gema Insani Press, 2006.

Muhammad Muslehuddin. Asuransi Dalam Islam. Jakarta: Bumi Aksara, 2004.

Muhammad Muslehuddin. Menggugat Asuransi Modern: Mengajukan Suatu Alternatif Baru Dalam Perspektif Hukum Islam. Jakarta: Lintera, 1999.

Muntahari, Murtadho. Pandangan Islam Tentang Asuransi Dan Riba. Bandung: Pustaka Hidayah, 1995.

Muslehuddin, Muhammad. Menggugat Asuransi Modern: Mengajukan Suatu Alternatif Baru Dalam Perspektif Hukum Islam. Jakarta: Lintera, 1999.

Qardhawi, Yusuf. Daur Al-Qiyam Wa Al-Akhlāq Fī Al- Iqtị̦ād AlIslām. Cairo: Muassasah al-Risalah, 2002.

Rikza Maulana. Perbandingan Sistem Asuransi Syariah Dan Konvensional. Indonesia: Takaful Indonesia, n.d.

S, Burhanuddin. Aspek Hukum Lembaga Keuangan Syariah. Yogyakarta: Graha Ilmu, 2010.

Sandra, Ketut. Konsep Dan Penerapan Asuransi Jiwa Unit-Link Proteksi Sekaligus Investasi. Yogyakarta: Bayu Indra Grafika, 2004.

Sharifuddin. "The Concept of Takaful (Islamic Insurance) and Its Functions in the Establishment of Syarikat Takaful Malaysia; the First Takaful Operator in Malaysia." InternationalJournal 
of Humanities and Social Science Invention 5, no. 12 December (2016): 43-48.

Sofiniyah Ghufron. Sistem Operasional Asuransi Syariah. Jakarta: Renaissan, 2005.

Suhendi, Hendi, and Yusuf. Asuransi Takaful: Dari Teoritis Ke Praktis. Bandung: Mimbar Pustaka, 2005.

Sula, Muhammad Syakir. Asuransi Syariah (Life \& General). Jakarta: Gema Insani Press, 2004.

Sweet, and Maxwell. Kontekstualisasi Takaful Dalam Asuransi Modern. Jakarta: UIN Syarif Hidayatullah, 2010.

Syahatah, Husain. Asuransi Dalam Perspektif Syariah. Jakarta: Amzah, 2006.

Tajuddeen Olalekan Yusuf. "Prospects of Takaful's (Islamic Insurance) Contributions to the Nigerian Economy." Journal of Finance and Investment Analysis 1, no. 3 (2012): 217-30.

Warkum Sumitro. Asas-Asas Perbankan Islam \& Lembaga-Lembaga Terkait. Jakarta: Rajawali Press, 1996.

Wirdyaningsih. Bank Dan Asuransi Islam Di Indonesia. Jakarta: Kencana, 2005.

Zainuddin Ali. Hukum Asuransi Syariah. Jakarta: Sinar Grafika, 2008. 